\title{
Accessibility to public health facilities by public transportation and health inequalities in São Paulo
}

Pauline losti

\section{(2) OpenEdition}

\section{Journals}

Electronic version

URL: http://journals.openedition.org/rfst/825

DOI: $10.4000 /$ rfst.825

ISSN: 2492-3672

\section{Publisher}

Espaces et SOciétés (UMR 6590)

\section{Electronic reference}

Pauline losti, "Accessibility to public health facilities by public transportation and health inequalities in São Paulo", Revue francophone sur la santé et les territoires [Online], Mobility, Transports and Health, Online since 27 May 2019, connection on 06 April 2021. URL: http://journals.openedition.org/rfst/825 ; DOl: https://doi.org/10.4000/rfst.825

This text was automatically generated on 6 April 2021.

\section{(i)(2)}

La Revue francophone sur la santé et les territoires est mise à disposition selon les termes de la Licence Creative Commons Attribution - Pas d'Utilisation Commerciale - Partage dans les Mêmes Conditions 4.0 International. 


\title{
Accessibility to public health facilities by public transportation and health inequalities in São Paulo
}

\author{
Pauline losti
}

1 This paper aimed to identify the role played by transportation and distance in access to health care for the population using the Brazilian public health care system and to assess the impact on health inequalities in the city of São Paulo.

2 The data come from a qualitative study carried out in a central area of São Paulo in 2017-2018. Interviews were led with the regulatory staff of the regional and local health administration, and with 37 users of the public health system.

In São Paulo, access to specialized care is regulated by administrators of the primary health care facilities, who are in charge of taking all of the users' appointments in specialized public health care. The users' health mobilities are thus constrained, in an urban context already constrained by transportation and traffic issues. 
Figure: Localization and accessibility by public transportation of the specialized health care facilities used by the regulation of the studied UBS in 2017

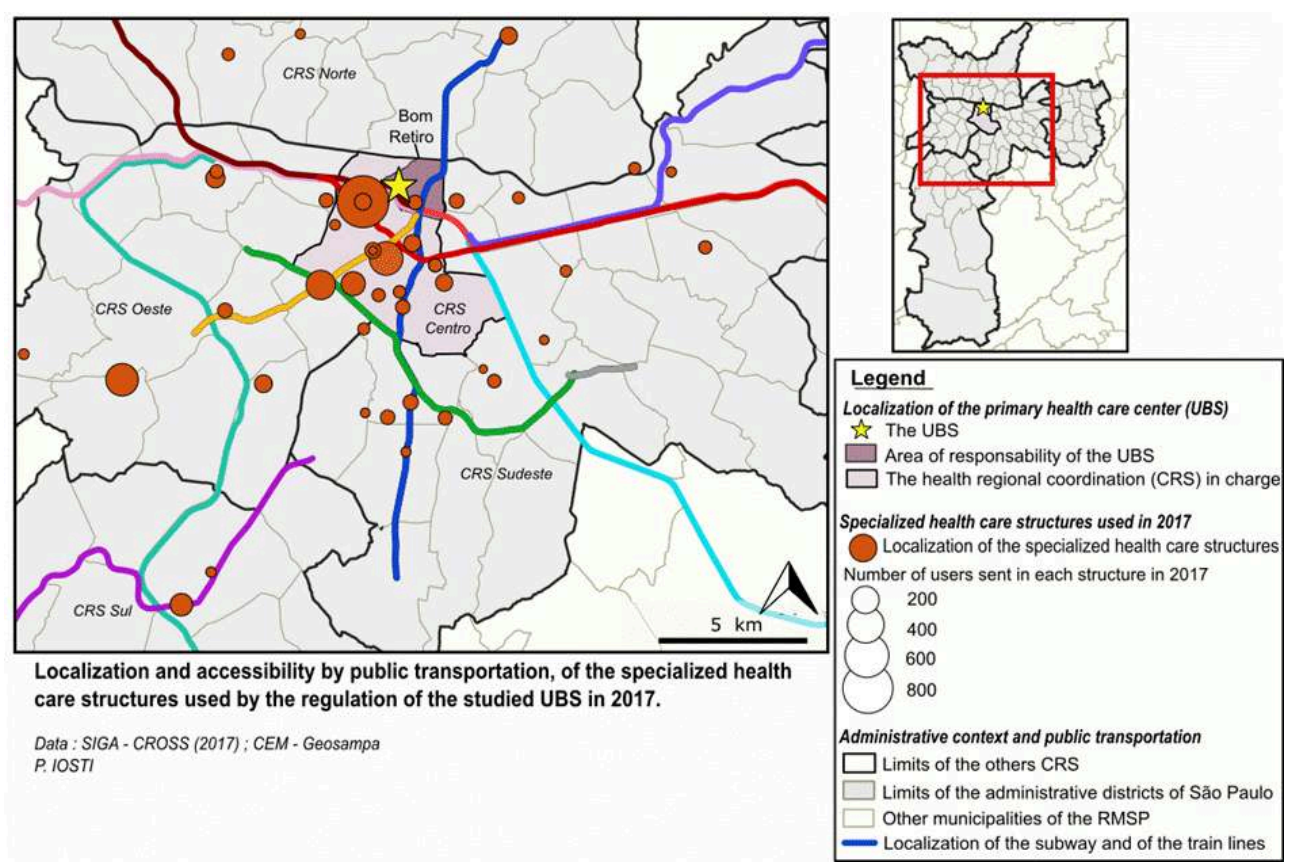

4 The interviews with regulators revealed that they try as much as they can to take into account accessibility to specialized health care by public transportation. This adaptation occurs by two means: by trying to choose the best locations when negotiating with the municipal administration, and by knowing the physical abilities of their patients. However, their own representation of acceptable distance is not necessarily the same as the users', and the spatial barriers to mobility that are considered in the regulatory process do not acknowledge the existence of mental barriers. Thus, the regulators' practices, though helping to organize a theoretically accessible health care system, are not sufficient to lower the very high absenteeism in specialized consultations.

5 The impact of transportation on the representation of proximity and distance to health care was then evaluated, in order to identify possibly remaining barriers in term of access. The users' interviews enabled us to conclude that public transportations were used by local populations to assess the distance to a health care facility, and that transportation could be an obstacle to access and was a potential source of discontent. However, it only became a real access barrier when associated with other factors, like waiting time for consultations, the urgency of the health care problem, the acceptability of the facility or of the doctor, or the location of the facility.

6 Finally, we tried to study the impact of two alternatives on health mobility. The first one was the availability of a personal or a family car. Even though it does not change the perception of distance, having access to a private car allows users to have better mobility options and less restrictions on access to health facilities they preferred or where they were sent. The second one was paying for a private health plan: users that had access to private care generally used it in order to get consultations in locations of their choice, either in areas close to their home or workplace, or in locations considered as accessible given their own mobility capacities. 
7 These alternatives were not equally distributed amongst the interviewees, and previous studies showed that these alternatives are more frequently available to the more affluent and educated population, proving that accessibility and mobility to health care are reproducing health inequalities. Moreover, these results allow us to infer that these prior inequalities contribute to various urban health trajectories. These trajectories appear to be more constrained for those with less health care or mobility options, thus accentuating health inequalities in São Paulo.

INDEX

Keywords: accessibility, public health, transports, health inequalities

Geographical index: Brazil, São Paulo

\section{AUTHOR}

PAULINE IOSTI

Doctorante, Université Lyon 3 Jean Moulin - UMR 5600 Environnement Ville société 